\title{
EFFECTS OF STATINS ON LIPID AND CARBOHYDRATE METABOLISM IN PATIENT WITH TYPE 2 DIABETES AND CARDIOVASCULAR DISEASES.
}

\author{
A. Briukhova, B. Mankovsky, I. Kondratska \\ P.L. Shupyk National Medical Academy of Post-graduate Education, Kiev, Ukraine
}

\section{Objectives:}

\section{Methods:}

\section{Results:}

Patients with diabetes mellitus (DM) type 2 is a group of high cardiovascular risk. The incidence of coronary heart disease in their 2-4 times higher than in the population without diabetes, $80 \%$ of cases of diabetes combined with hypertension. At the same time any change in lipid metabolism leads to increased cardiovascular risk in patients with type 2 diabetes. Statins is first-line drugs in patients with dyslipidemia.

The study involved 15 patients with type 2 diabetes and dyslipidemia in mean age 59,8 81,03 years, among them, 11 women and 4 male. All patients was prescribed statins in mean dose $4 \mathrm{mg}$ per day for 3 month. During the study were determined the levels of glycated hemoglobin $(\mathrm{HbA} 1 \mathrm{c})$ and lipid status before and after treatment.

\begin{tabular}{|l|l|l|l|l|l|}
\hline & $\begin{array}{l}\text { Total } \\
\text { cholesterol }\end{array}$ & Triglycerides & $\begin{array}{l}\text { Low-density } \\
\text { lipoprotein }\end{array}$ & $\begin{array}{l}\text { Very low density } \\
\text { lipoproteins }\end{array}$ & $\begin{array}{l}\text { High-density } \\
\text { lipoprotein }\end{array}$ \\
\hline $\begin{array}{l}\text { Before } \\
\text { treatment } \\
(n=15)\end{array}$ & $5,64 \pm 0,2$ & $1,77 \pm 0,2$ & $3,73 \pm 0,2$ & $0,51 \pm 0,05$ & $1,49 \pm 0,08$ \\
\hline $\begin{array}{l}\text { After } \\
\text { treatment } \\
(n=15)\end{array}$ & $4,38 \pm 0,2 *$ & $1,65 \pm 0,2$ & $2,53 \pm 0,2 *$ & $0,51 \pm 0,06$ & $1,48 \pm 0,08$ \\
\end{tabular}

Analyzing the results obtained in the groups of patients a significant decrease in levels of total cholesterol, low-density lipoprotein. Triglyceride levels decreased to normal range after 3 months. Statistically significant increase in glycated hemoglobin was not confirmed.

Application of statin leads to the likely reduction in levels of total cholesterol, low density lipoprotein, indicating that effective treatment of dyslipidaemia in patients with type 2 diabetes. Statistically significant effect on glycated hemoglobin was not observed. 